\title{
Effect of Nitrogen Fertilization on the Photosynthetic Activity, Growth and Yield of Virginia Tobacco (Nicotiana tabacum L.)
}

\author{
by \\ Lorenzo Covarelli \\ Dipartimento di Scienze Agroambientali e della Produzione Vegetale \\ Sezione di Agronomia Generale e Coltivazioni Erbacee \\ Università degli Studi di Perugia, Italia
}

\section{SUMMARY}

A field experiment was carried out in 1996 in Central Italy in order to evaluate the effects of nitrogen fertilization $\left(0,60,120 \mathrm{~kg} \mathrm{ha}^{-1} \mathrm{~N}\right)$ of Virginia tobacco (cv. K394) in terms of net assimilation, growth and yield. Measurements of net leaf assimilation of $\mathrm{CO}_{2}$ were taken at midday under conditions of strong sunlight $\left(A n_{b i g h}\right)$ using a portable infra-red gas analyzer and at decreasing photosynthetic photon flux density by shading the leaves with filters (An vs PPFD). For $A n$ vs PPFD measurements the $A n_{\max }$ value was calculated as the asymptote of the function proposed by CONNOR et al. (1). Growth was analysed by taking weekly samples to determine the fresh and dry weight and LAI (Leaf Area Index).

Before topping, $A n_{b i g b}$ (average assimilation found in lower, middle and upper leaves) rose in proportion to increased levels of $\mathrm{N}\left(14.7,17.2,20.2 \mu \mathrm{mol} \mathrm{m}^{-2} \mathrm{~s}^{-1}\right.$, for 0 , 60 and $120 \mathrm{~kg} \mathrm{ha}^{-1} \mathrm{~N}$ respectively). After topping, $A n_{\text {bigh }}$ also grew with increased levels of $\mathrm{N}$, but at a lower rate (6.8, 7.2 and $8.2 \mu \mathrm{mol} \mathrm{m}^{-2} \mathrm{~s}^{-1}$, respectively).

Similarly, for each of the three fertilization methods (NO, $\mathrm{N} 60$ and $\mathrm{N} 120$ ) the increase in $A n_{\max }$ in relation to $\mathrm{N}$ levels was greater before topping than afterwards (i.e. $18.7,23.3,26.3 \mu \mathrm{mol} \mathrm{m}^{-2} \mathrm{~s}^{-1}$ before topping compared to 7.5, 14.0 and $17.8 \mu \mathrm{mol} \mathrm{m}{ }^{-2} \mathrm{~s}^{-1}$ after topping for each treatment respectively). The decrease of $\mathrm{CO}_{2}$ assimilation

after topping was probably caused by the accumulation of soluble photo assimilates in the leaf which could have led to a feed-back control on leaf photosynthesis. In N60 and N120 treatments, which had the same leaf expansion rate of $0.14 \mathrm{~m}^{2} \mathrm{~m}^{-2} \mathrm{~d}^{-1}$ ( $\mathrm{m}^{2}$ of leaf on $\mathrm{m}^{2}$ of soil per day), the rapid leaf expansion phase started about 40 days after transplanting, while it started some days later in No (rate of $0.11 \mathrm{~m}^{2} \mathrm{~m}^{-2} \mathrm{~d}^{-1}$ ). That phase ended at topping in $\mathrm{N} 60$ and N120, while in NO it ended some days before topping. Biomass accumulation followed the same pattern of LAI. The rapid biomass accumulation phase was characterised by growth rates of 9,16 and $19 \mathrm{~g} \mathrm{~d} . \mathrm{m} . \mathrm{m}^{-2} \mathrm{~d}^{-1}$, respectively for the N0, N60 and N120 treatments but did not end at topping. This confirms that assimilate accumulation occurred after topping but was not accompanied by leaf expansion.

At fertilization rates of 0,60 and $120 \mathrm{~kg} \mathrm{~N} \mathrm{ha}^{-1}$ the yields of cured leaf tobacco were 3226, 4202 and $4839 \mathrm{~kg} \mathrm{ha}^{-1}$ respectively.

\section{ZUSAMMENFASSUNG}

Ein Feldexperiment wurde 1996 in Mittelitalien durchgeführt um den Einfluß der N-Düngung $(0,60,120 \mathrm{~kg}$ $\mathrm{ha}^{-1} \mathrm{~N}$ ) auf die Netto-Assimilationsrate der Blätter von Virginia-Tabak (cv. K394) zu bewerten. Die $\mathrm{CO}_{2}$-Assimi- 
lation der Blätter wurde um die Mittagszeit bei hoher $\left(A n_{\text {high }}\right)$ und bei mit Filtern reduzierter Lichteinstrahlung (An vs PPFD) mit Hilfe eines tragbaren IRGasanalysators gemessen $(P P F D=$ photosynthetic photon flux density). $A n_{\text {bigh }}$ wurde periodisch während der gesamten Wachstumsphase des Tabaks an den oberen, mittleren und unteren Blättern ermittelt, während $A n$ vs PPFD zu zwei verschiedenen Zeiten der Wachstumsperiode an den mittleren Blättern gemessen wurde. Für jede $A n$ vs PPFD-Messung wurde der $A n_{\max }$-Wert über die Asymptote zu der von CONNOR et al. (1) vorgeschlagenen Funktion errechnet. Während der Wachstumsphase ist $A n_{\text {bigh }}$ bis zu Maximalwerten proportional der eingesetzten $\mathrm{N}$ Menge angestiegen (im Mittel 14.7, 17.2, $20.2 \mu \mathrm{Mol}$ $\mathrm{m}^{-2} \mathrm{~s}^{-1}$ für $0,60 \mathrm{bzw} .120 \mathrm{~kg} \mathrm{~N} \mathrm{ha}{ }^{-1}$ ). Nach dem Köpfen gingen die $A n_{\text {bigh }}$-Werte im Mittel auf 6.8, 7.2 bzw. $8.2 \mu \mathrm{Mol} \mathrm{m}^{-2} \mathrm{~s}^{-1}$ für die drei N-Düngungsstufen zurück. Die Assimilationsrate war in den oberen und mittleren Blättern stets höher als in den unteren Blättern. Die $A n_{\max }$-Werte waren in N120 immer höher als bei N60 und N0, in N60 meistens höher als bei NO. $A n$ und $A n_{\max }$ waren positiv korreliert mit den prozentualen N-Gehalten der Blätter bis zum Grenzwert von $2 \% \mathrm{~N}$.

\section{RESUME}

Une étude en plein champ a été menée en Italie Centrale pour évaluer l'effet de la fertilisation azotée $\left(0,60,120 \mathrm{~kg} \mathrm{ha}^{-1} \mathrm{~N}\right)$ sur le taux net d'assimilation par les feuilles de la variété Virginie cv. K394. L'assimilation foliaire du $\mathrm{CO}_{2}$ a été mesurée vers midi, pour des intensités de radiation élevée $\left(A n_{\text {bigh }}\right)$ et réduite ( $A n$ vs PPFD), utilisant un écran, au moyen d'un appareil portatif d'analyse des gaz par infrarouge (ADC-LCA3). Les mesures $A n$ on été faites périodiquement pendant tout le cycle de culture du tabac, directement sur les feuilles basses, médianes et supérieurs, tandis que les mesures $A n$ vs PPFD (PPFD $=$ photosynthetic photon flux density) ont été prises à deux époques de la culture sur les feuilles médianes. Pour chaque mesure $A n$ vs PPFD une valeur $A n_{\max }$ égale à l'asymptote supérieure de la fonction proposée per CONNOR et al. (1) a été calculé. Au cours du cycle de culture, $A n$ augmente jusqu'à des valeurs maximum proportionnelles à la dose d'azote appliquée $\left(14.7,17.2,20.2 \mu \mathrm{mol} \mathrm{m}^{-2} \mathrm{~s}^{-1}\right.$ en moyenne, pour les doses d'azote de 0,60 et $120 \mathrm{~kg} \mathrm{ha}^{-1}$ respectivement). Après écimage, $A n$ décrô̂t jusqu'à des valeurs de $6.8,7.2$ et $8.2 \mu \mathrm{mol} \mathrm{m} \mathrm{m}^{-2} \mathrm{~s}^{-1}$, en moyenne, respectivement pour les trois niveaux de fertilisation azotée. Le taux d'assimilation est toujours plus élevé chez les feuilles supérieures et médianes que chez les feuilles basses. Les valeurs $A n_{\max }$ sont toujours plus élevées pour N120 que pour N60 et, plus encore pour N60 que pour No. $A n$ et $A n_{\max }$ sont liés positivement aux teneurs en azote dans les feuilles, jusqu'au seuil de $2 \%$.

\section{INTRODUCTION}

Research to improve our understanding of why photosynthesis differs in different leaves, particularly under sub-optimal conditions, has assumed increasing importance in agricultural and environmental science (5). It has also become a key goal in the research of Virginia tobacco (3). Nitrogen fertilization (Nfertilization) strongly influences both the photosynthetic capacity of plants and leaf area $(6,9)$. Greater scientific knowledge about how $\mathrm{N}$ rates affect crop photosynthesis and growth will enable farmers to perfect $\mathrm{N}$-fertilization strategies and thus optimise quality and yield.

The purpose of the present work was to determine the effects of nitrogen fertilization and topping on photosynthetic activity, growth and yield with the Virginia tobacco variety K394. This variety, which has proven one of the best in terms of yield and quality (2) is one of the most widely planted tobaccos in Umbria (Central Italy) which is a typical area for the cultivation of Virginia tobacco.

\section{MATERIALS AND METHODS}

An experimental field study was carried out in 1996 at the Experimental Station of the Department of Agroenvironmental and Crop Science of the University of Perugia, Italy ( $42^{\circ} 57^{\prime} \mathrm{N}$ latitude, $165 \mathrm{~m}$ a.s.1.) on a clay-loam, silt soil with $1.2 \%$ organic matter. In order to reduce the mineral nitrogen content of the soil and make it more uniform in character a crop of oats was grown and harvested before the area was used for the tobacco trial. On 28 May, seedlings of the Virginia flue-cured tobacco variety K 394, grown in a float-system, were transplanted at a density of 2 plants per $\mathrm{m}^{2}$ in rows $1 \mathrm{~m}$ apart. The soil was fertilized with $120 \mathrm{~kg} \mathrm{P}_{2} \mathrm{O}_{5} \mathrm{ha}^{-1}$ and $125 \mathrm{~kg} \mathrm{~K}_{2} \mathrm{O} \mathrm{ha}^{-1}$.

In a complete randomised design with 3 replicates, three levels of $\mathrm{N}$-fertilizer were employed $(\mathrm{O}=\mathrm{NO}$, $60=\mathrm{N} 60$ and $120=\mathrm{N} 120 \mathrm{~kg} \mathrm{~N} \mathrm{ha}^{-1}$ ). The purpose of the study was to compare an unfertilized control (No) with $\mathrm{N} 60$ - the norm in cultivation of Virginia tobaccos in Central Italy - and N120 - a very high level of fertilization - in order to determine the maximum response of Virginia tobacco to nitrogen fertilization.

Each of the experimental plots covered a net area of $140 \mathrm{~m}^{2}$ on which the crop was planted in 7 rows of 
forty. Part of each plot was used to assess LAI (Leaf Area Index) and biomass (calculated by adding the LAI and biomass values of harvested and topped leaves to the actual LAI and biomass). The remaining part of each plot was used to determine photosynthetic activity, topping date and yield. Weekly samples were taken to assess growth. To this end, four plants were cut at ground level and the middle plants used: one to determine fresh and dry weight (stem, leaves, flowers) and the other to determine LAI using the Hayashi Denco area meter. The N-fertilizer utilised was ammonium nitrate, which was spread over the entire plot a few days after transplanting. The plot was irrigated using the trickling method, with one irrigation line for each plant row and an hydrovalve ensuring $100 \%$ restoration of the ETPc (calculated evapotranspiration). ETPc was measured daily on the basis of Class A pan evaporation and then multiplied for the crop coefficients, according to the stage of plant development and the number of harvests to date.

Tobacco was manually topped at the early flowering stage, above the $20^{\text {th }}$ leaf and the wound treated with a $4 \%$ n-decanol water solution to prevent lateral sucker growth. Moreover, in order to complete the action of the preceding treatment, $41 \mathrm{ha}^{-1}$ of maleic hydrazide were sprayed early in September.

Yield was determined by harvesting the leaves at six different times (according to the stage of ripeness) and weighing the fresh and flue-cured leaves (adjusted to $15 \%$ humidity content).

Net $\mathrm{CO}_{2}$ leaf assimilation $(A n)$ was measured using a portable infra-red gas-analyser (ADC-LCA3) on fully sunlit leaves when the sun's radiation level (Photosynthetic Photon Flux Density, PPFD) was at its most intensive daily level $\left(A n_{\text {bigh }}\right)$ and at decreasing PPFD (An vs PPFD) by shading the leaf chamber with Kodak filter in order not to alter the spectrometric composition of solar radiation.

$A n_{\text {bigh }}$ measurements were taken on a weekly basis on the lower, middle and upper leaves of two plants per plot, starting on $17 \mathrm{July}, 50$ days after transplanting $(\mathrm{DAT}=$ days after transplanting ), until 5 September (105 DAT).

An vs PPFD measurements were taken on 9 and 25 August (73 and $89 \mathrm{DAT}$ ) on the middle leaves of two plants per plot. For each $A n$ vs PPFD measurement the $A n_{\max }$ value was calculated as the upper asymptote of the function proposed by CONNOR et al. (1):

$$
A n=\left(A n_{\max }+\mathrm{R}\right) \cdot\left(1-e^{\left(-\frac{\Phi \cdot P P F D}{A n_{\max }+\mathrm{R}}\right)}\right)-\mathrm{R}
$$

where $\mathrm{An}_{\max }$ is the $\mathrm{CO}_{2}$ assimilation at saturating irradiance levels, $\mathrm{R}$ the dark respiration rate and the apparent quantum efficiency. This model was adjusted to observed data by non-linear regression analysis, using the NLIN procedure of SAS (7).

In oder to determine $\mathrm{N}$ levels, leaf discs of approximately $10 \mathrm{~cm}^{2}$ were cut immediately after measurement for $\mathrm{CO}_{2}\left(A n_{b i g h}\right.$ and $A n$ vs PPFD), these were oven dried at $80^{\circ} \mathrm{C}$ and analysed by the Kjeldahl method.

Weather patterns for the period May to October 1996 (rainfall and average decadic temperature) were compared with the average rainfall during the last 76 years and temperature over the last 44 years during the same period.

\section{RESULTS AND DISCUSSION}

The rainfall recorded from May to October (Figure 1) was $514 \mathrm{~mm}$ compared with an average (over 76 years) of $401 \mathrm{~mm}$ during the same period. Beneficial rainfall $(>10 \mathrm{~mm}$ ) brought about $320 \mathrm{~mm}$ of water to the crop, 190 of which fell in August and September. Compared to the past 44 years average decadic temperatures were higher in the period immediately after planting, close to the July average and below the averages for August and September. The low temperature at the end of the cycle did not allow an optimal ripening of tobacco which ended in mid October. According to the results of LIU H. and LIU Z. (4), the middle and upper leaves generally exhibit higher $A n_{\text {bigh }}$ values than the lower ones (Figure 2). In all Ntreatments, leaf $\mathrm{CO}_{2}$ assimilation increased (average 14.7, 17.2, $20.2 \mu \mathrm{mol} \mathrm{CO} \mathrm{Cm}^{-2} \mathrm{~s}^{-1}$ for the 0,60 and $120 \mathrm{~N}$-fertilization levels respectively) until about 65 $\mathrm{DAT}$, at least in upper and middle leaves, and decreased in all the leaves thereafter. After topping and during the harvesting season, $A n_{\text {bigh }}$ decreased to average values of $6.8,7.2$ and $8.2 \mu \mathrm{mol} \mathrm{CO} \mathrm{m}^{-2} \mathrm{~s}^{-1}$ for N0, N60 and N120, respectively.

$\mathrm{N}$-fertilization affected the $A n$ vs PPFD response curve. $A n_{\max }$ increased in accordance with the $\mathrm{N}$ rate (Figure 3 and Table 1) - confirming the findings of GUIDUCCI $e t$ al. (3) - and decreased at all levels of $\mathrm{N}$ from 9 August (73 DAT) to 25 August (89 DAT). In fact, at $73 \mathrm{DAT}$, assimilation rates of 18.7, 23.3, 26.3 $\mu \mathrm{mol} \mathrm{m} \mathrm{m}^{-2} \mathrm{~s}^{-1}$ were found, respectively for the NO, $\mathrm{N} 60$ and N120 treatments, while at 89 DAT, the rates were $7.5,14.0$ and $17.8 \mu \mathrm{mol} \mathrm{m} \mathrm{m}^{-2} \mathrm{~s}^{-1}$, in the three treatments. The decrease of $\mathrm{CO}_{2}$ assimilation as the period of growth processed can probably be explained by leaf senescence and, as shown by LAI development, the accumulation of assimilates induced by topping, which probably caused 


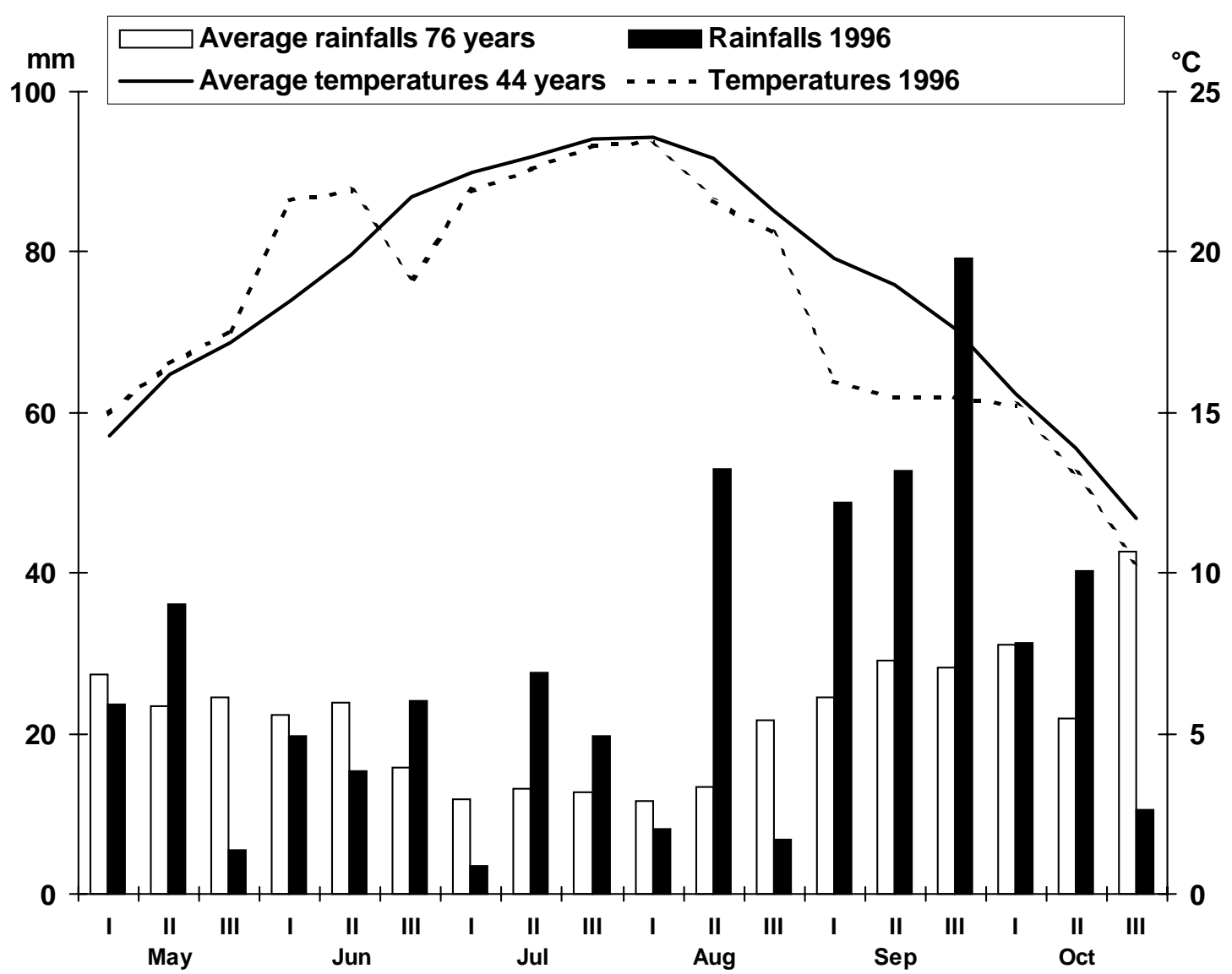

Figure 1.

Weather pattern during tobacco cycle.

a feed-back control on photosynthesis. The increase of photo-synthetic activity from the lower to the upper leaves (Figure 4) corresponded to increasing leaf nitrogen content. Particularly in the lower and middle leaves, a clear relation between nitrogen content and $A n_{b i g h}$, up to a threshold of about $2.5 \%$ nitrogen content, was recorded. A linear relationship $\left(\mathrm{R}^{2}=0.95\right)$ between $A n_{\max }$ and nitrogen content was also found (Figure 5). It should be noted that the low photosyn-thetic rate recorded at 89 DAT was related to the lower nitrogen content of leaves induced by senescence. Indeed, PAUL and DRISCOLL (8) found that the withdrawal of nitrogen in tobacco induced a corresponding decrease in the rate of photosynthesis, accompanied by a large decrease in the amount and activity of Rubisco (ribulose bisphosphate carboxylase oxigenase).

In N60 and N120 treatments (Figure 6), the rapid leaf expansion phase (rate of $0.14 \mathrm{~m}^{2}$ of leaf on $\mathrm{m}^{2}$ of soil per day) started about 40 DAT and ended about 80 DAT (topping), while in $\mathrm{NO}$ treatment it started about 10 days later, also ending on $80 \mathrm{DAT}$. This caused a lower LAI value in NO compared to the other two treatments (rate of $\left.0.11 \mathrm{~m}^{2} \mathrm{~m}^{-2} \mathrm{~d}^{-1}\right)$.

Biomass accumulation (Figure 7) followed the same pattern of LAI values (starting about $40 \mathrm{DAT}$ in the case of N60 and N120, compared to N0 which started some days later) while growth rates of 9,16 and $19 \mathrm{~g} \mathrm{~d} . \mathrm{m} . \mathrm{m}^{-2}$ $\mathrm{d}^{-1}$ were recorded respectively for the No, N60 and N120 treatments. The rapid biomass accumulation continued after the end of leaf expansion (topping), indicating an increase of leaf specific fresh and dry weight.

Yields of cured leaves obtained with 0,60 and $120 \mathrm{~kg} \mathrm{~N}$ $\mathrm{ha}^{-1}$ were 3226, 4202 and $4839 \mathrm{~kg} \mathrm{ha}^{-1}$ respectively. A statistically significant linear relationship $\left(\mathrm{R}^{2}=0.99\right)$ between the level of nitrogen applied and yield has been documented (Figure 8), indicating a $13.4 \mathrm{~kg} \mathrm{ha}^{-1}$ increase of cured leaves for each additional kilogram of applied nitrogen. The high yield is explained by the long rotation, optimum water supply (irrigation plus high rainfall 


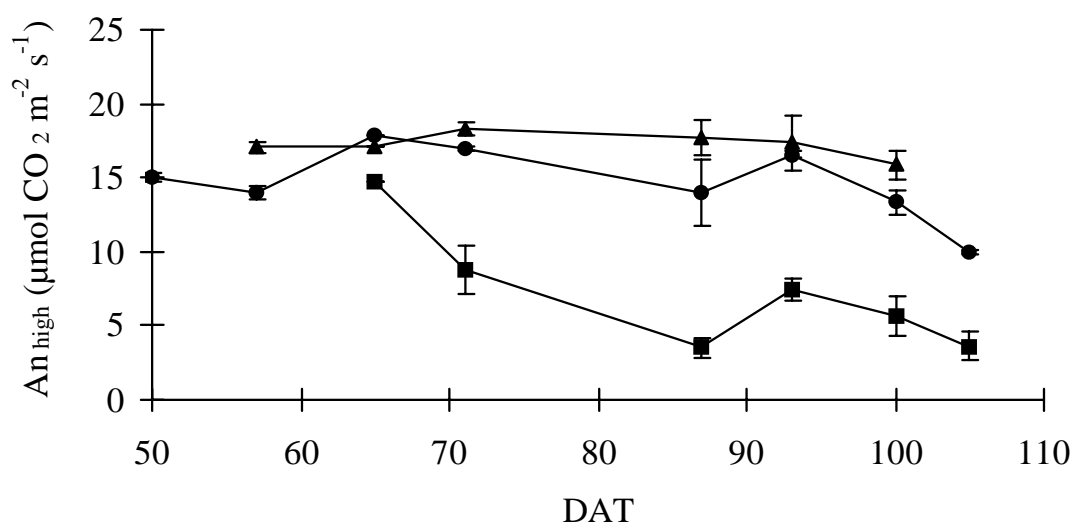

N 60

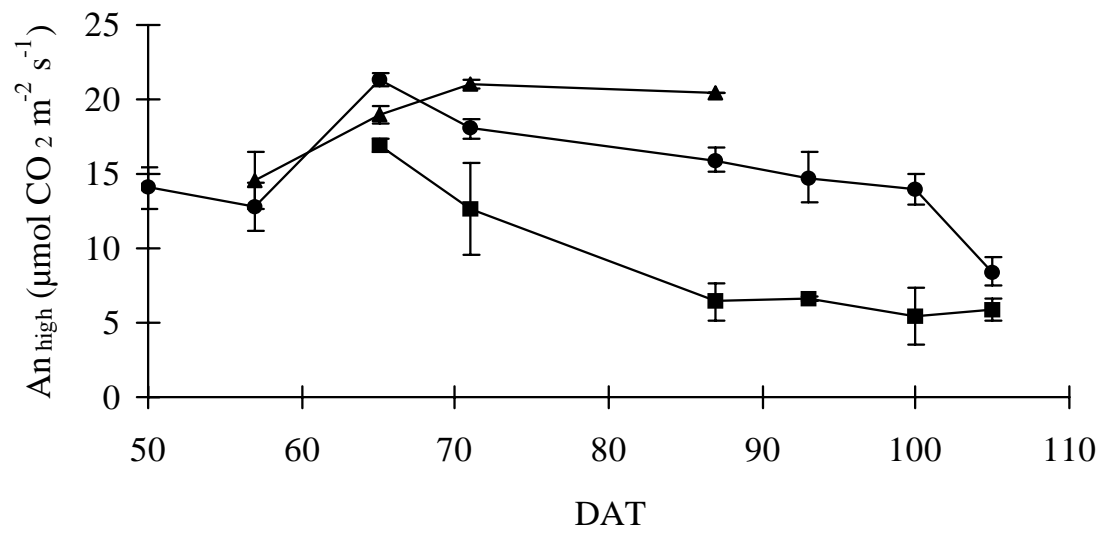

N 120

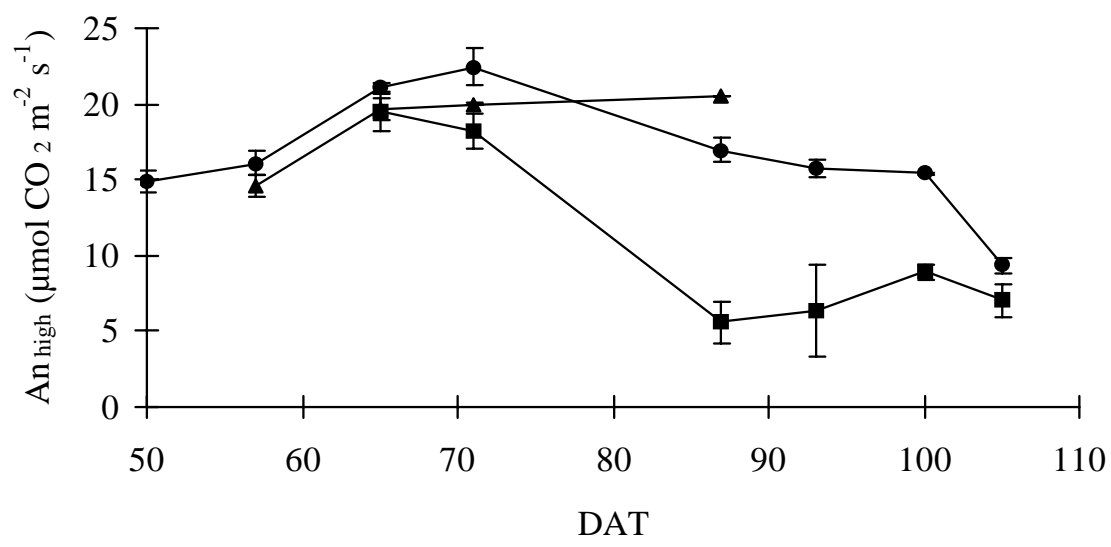

Figure 2.

$\mathrm{CO}_{2}$ assimilation

$\left(A n_{\text {high }}\right)$ course in

time in lower $(\square)$, middle $(\bullet)$ and upper $(\Delta)$ leaves of tobacco subjected to

different $\mathrm{N}$-fertilization levels (DAT = days after transplanting, bars represent \pm s.e.). 

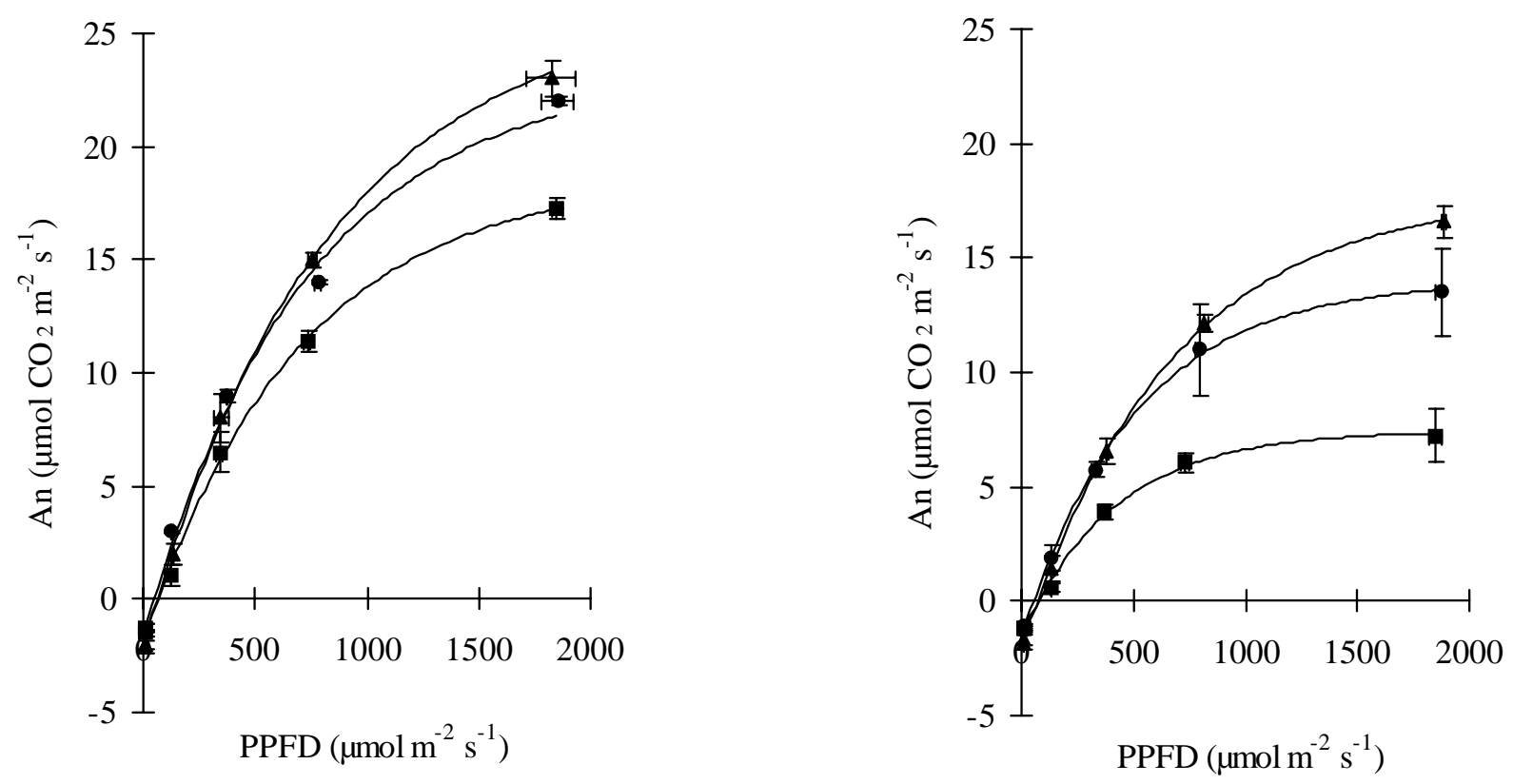

Figure 3.

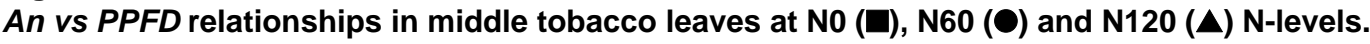

Measurements taken at 73 DAT (left) and 89 DAT (right). Bars represent \pm s.e.

throughout the cycle) and the good properties of the $\mathrm{K}$

nitrogen fertilization.

394 variety. All these factors optimize the effects of

Table 1.

Estimated parameter values of regression analysis of $A n$ vs PPFD $\left(\mu \mathrm{mol} \mathrm{CO}_{2} \mathrm{~m}^{-2} \mathrm{~s}^{-1}\right)$ measurements and their standard errors (in brackets).

\begin{tabular}{|c|c|c|c|c|}
\hline DAT & Parameters & No & N60 & N120 \\
\hline \multirow{3}{*}{73} & $A n_{\max }$ & $18.7(0.678)$ & $23.3(0.721)$ & $26.3(0.217)$ \\
\hline & $\mathrm{R}$ & $1.9(0.28)$ & $1.6(0.27)$ & $2.1(0.07)$ \\
\hline & $\Phi$ & $0.030(0.0019)$ & $0.034(0.0019)$ & $0.035(0.0004)$ \\
\hline \multirow{3}{*}{89} & $A n_{\max }$ & $7.5(0.281)$ & $14.0(0.297)$ & $17.8(0.198)$ \\
\hline & $\mathrm{R}$ & $1.5(0.19)$ & $1.6(0.17)$ & $2.1(0.09)$ \\
\hline & $\Phi$ & $0.021(0.0018)$ & $0.031(0.0015)$ & $0.030(0.0006)$ \\
\hline
\end{tabular}




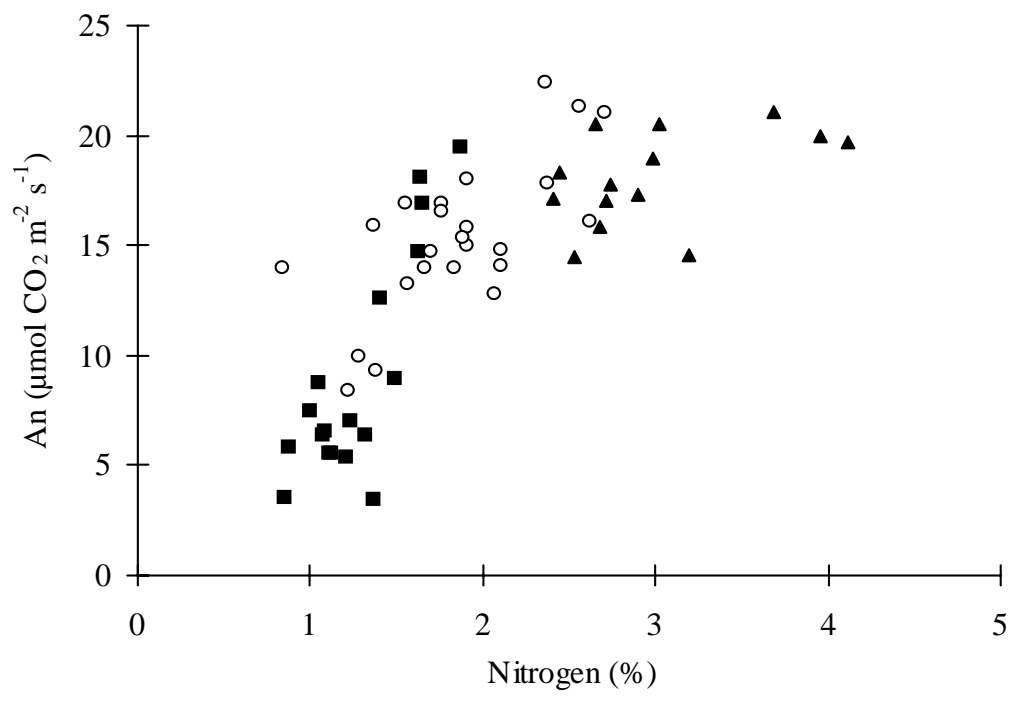

Figure 4.

$A n_{\text {high }}$ variation as a function of leaf nitrogen content in lower $(\square)$, middle $(O)$ and upper $(\boldsymbol{\Delta})$ tobacco leaves.

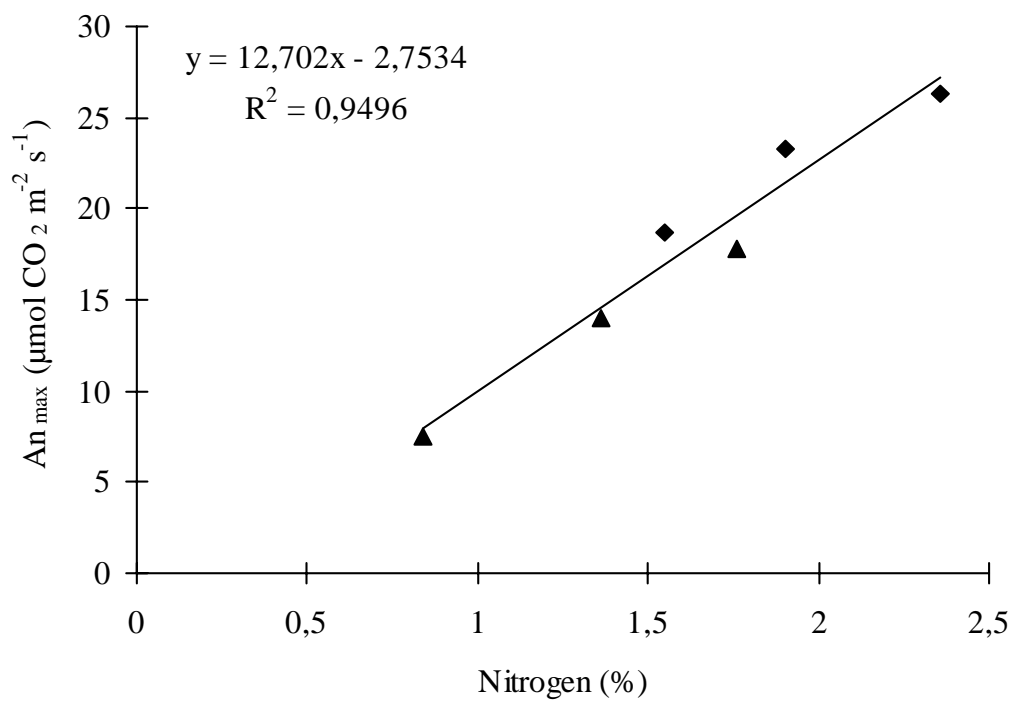

Figure 5.

Relationship between leaf nitrogen content and $A n_{\max }$ in tobacco at different nitrogen levels.

Measurements taken at 73 DAT $(\diamond)$ and 89 DAT $(\Delta)$. 


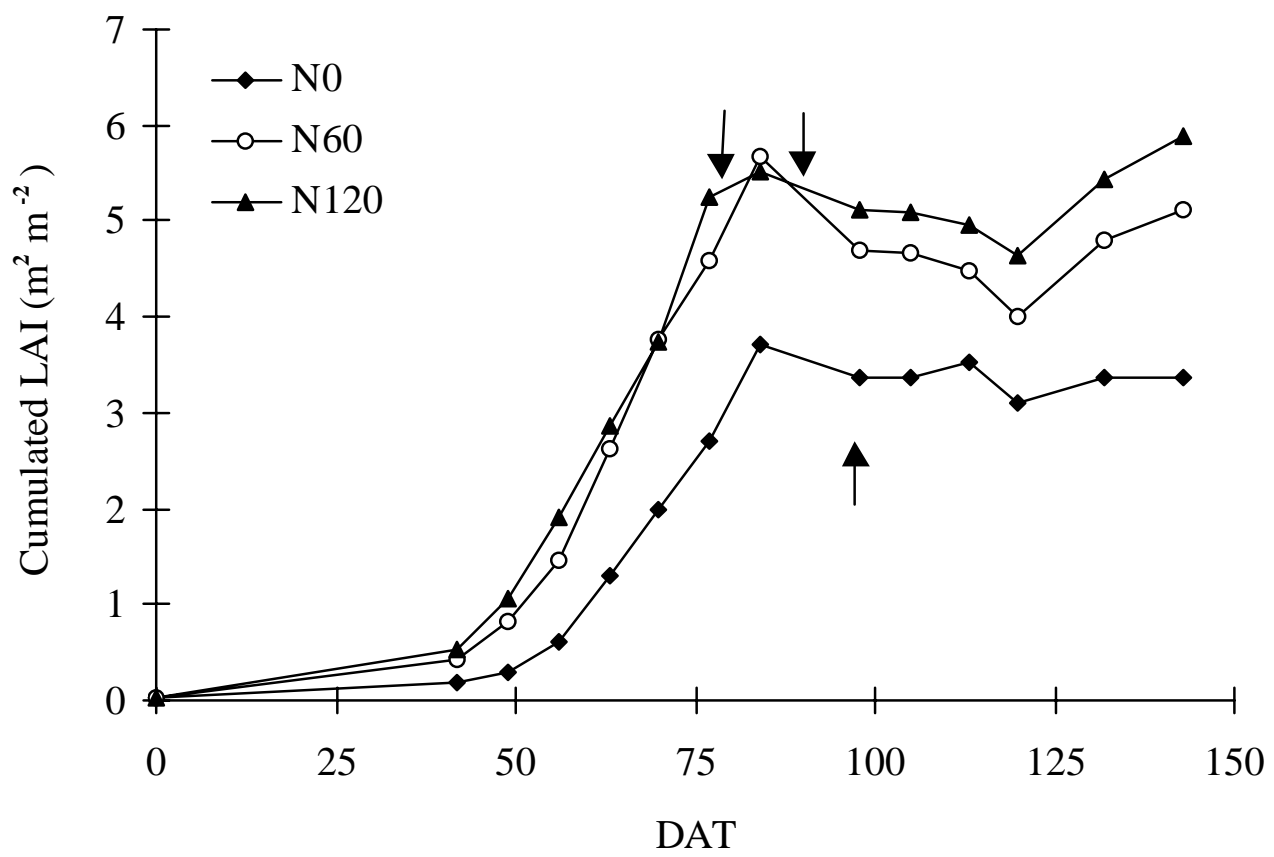

Figure 6.

Cumulated LAI (Leaf Area Index) course in time in tobacco at different nitrogen levels. Arrows indicate topping execution. (DAT = days after transplanting).

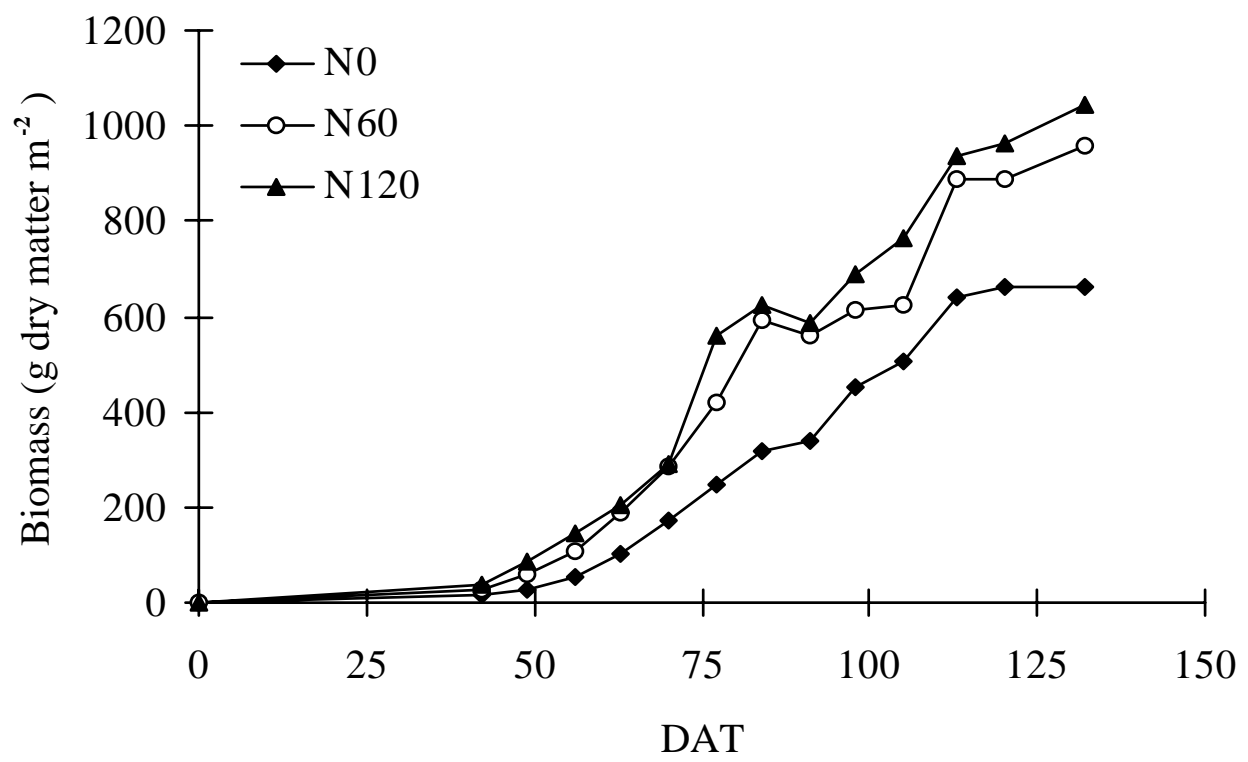

Figure 7.

Cumulated biomass course in time in tobacco at different nitrogen levels. (DAT = days after transplanting). 


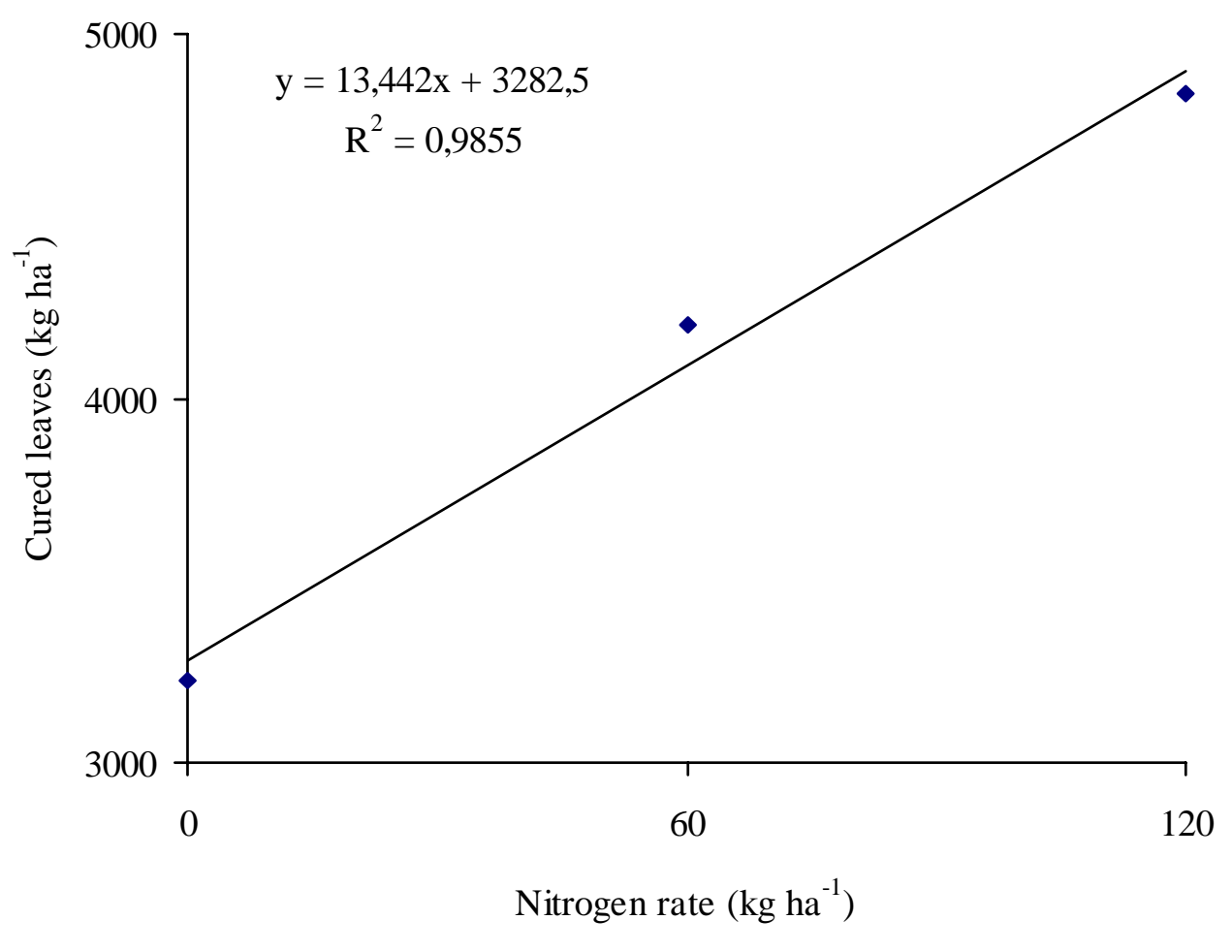

Figure 8.

Relationship between nitrogen fertilization rate and tobacco yield (cured leaves at $15 \%$ humidity).

\section{CONCLUSIONS}

The data obtained in this field experiment provide clear evidence of the positive effects of nitrogen on yields of Virginia tobacco in Umbria.

Net $\mathrm{CO}_{2}$ leaf assimilation increased with higher levels of $\mathrm{N}$-fertilization, with levels of concentration proceeding in degree from the lower to the upper leaves. This is due to the increased nitrogen content of the leaves (both $A n_{\text {bigh }}$ and $A n_{\max }$ were positively related to the $\% \mathrm{~N}$ content in the leaves, up to the threshold of about $2.5 \% \mathrm{~N} \mathrm{~d}$.m.). The maximum assimilation rates were recorded before topping. After topping there was a gradual accumulation of soluble assimilates in the leaves which caused a feedback control on photosynthesis, thus reducing the buildup of organic matter and yield. Nitrogen proved fundamental for tobacco: inducing higher $\mathrm{CO}_{2}$ assimilation rates and LAI and therefore enabling higher yields.

\section{REFERENCES}

1. Connor, D.J., A.J. Hall and V.O. Sadras: Effect of nitrogen content on the photosynthetic characteristics of sunflower leaves; Aust. J. Plant Physiol. 20 (1993) 251-263.

2. Covarelli, L., E. Rosati: Two years experiments on productive and qualitative characteristics and susceptibility to PVY virus of new Virginia tobacco varieties; Umbria Agricoltura 3 (1999) 44-49.

3. Guiducci, M., P. Benincasa and M. Migni: Effect of nitrogen fertilization on leaf photosynthesis and light absorption in tobacco; Book of Abstracts $4^{\text {th }}$ ESACongress, Wageningen, NL, 1996, pp. 554-555.

4. Liu, H. and Z. Liu: Study of physiological characteristics of flue-cured tobacco; Proceedings of the $9^{\text {th }}$ International Tobacco Scientific Congress, Guangzhou, China, 1988, pp. 106-107.

5. Long, S.P., P.K. Farage and R.L. Gracia: Measure- 
ment of leaf and canopy photosynthetic $\mathrm{CO}_{2}$ exchange in the field; J. Exp. Bot 304 (1996) 1629-1642.

6. Novoa, R. and R.S. Loomis: Nitrogen and plant production; Plant and Soil 58 (1981) 177-204.

7. SAS Institute Inc.: SAS Introductory Guide for Personal Computers, Release 6.03, SAS Institute, Cary, NC, 1988.

8. Paul, M.J. and S.P. Driscoll: Sugar repression of photosynthesis: The role of carbohydrates in signalling nitrogen deficiency through source-sink imbalance; Plant Cell Environ. 20 (1997) 110-116.

9. Sinclair, T.R.: Nitrogen influence on the physiology of crop yield; in: Theoretical Production Ecology: Reflections and Prospects by R. Rabbinge et al. (eds.); Pudoc, Wageningen, 1990, pp. 41-55.
Address for correspondence:

Dr. Lorenzo Covarelli

Dipartimento di Arboricoltura e Protezione delle Piante Borgo XX Gingno, 74

06121, Perugia, Italy

email:cova@krenet.it 